\title{
Human Rights and emotions from the perspective of the colonised: Anthropofagi, legal surrealism and subaltern studies
}

\section{Direitos Humanos e as emoções do ponto de vista dos colonizados: antropofagia, surrealismo jurídico e estudos subalternos}

\author{
José Manuel Barreto' \\ Humboldt University, Alemanha \\ barreto@rewi.hu-berlin.de
}

\begin{abstract}
The Third World can easily experience a form of ghost existence: We speak but are not heard. However, in our culture there are a number of trends and positions that are relevant to the task of thinking human rights in a new light. Among them, the critiques of rationalism advanced by Oswald de Andrade and Luis Alberto Warat in Brasil and Argentina - where there is a possibility of integrating the emotions into human rights theory. Sharing a preoccupation with those excluded from the 'world order' and the appeal to sensibility, Subaltern Studies have advanced some insights pointing at establishing a link between colonialism, human rights and suffering. This is the case in the work of Upendra Baxi, who has made a criticism ofWestern theorisations of law and crafted a fruitful encounter between the insights of Subaltern Studies and the theory of human rights.
\end{abstract}

Key words: Manifesto Antropófago, emotions, legal surrealism, Subaltern Studies, decolonial theory, Eurocentrism, human rights.

\section{Resumo}

OTerceiro Mundo pode facilmente experimentar uma forma de existência fantasma: nós falamos, mas não somos ouvidos. No entanto, na nossa cultura existe uma série de tendências e posições que são relevantes para a tarefa de pensar os direitos humanos sob uma nova luz. Entre elas, as críticas do racionalismo propostas por Oswald de Andrade e Luis Alberto Warat no Brasil e na Argentina, onde existe a possibilidade de integrar as emoções na teoria dos direitos humanos. Compartilhando uma preocupação com os excluídos da "ordem mundial" e o apelo à sensibilidade, os Estudos Subalternos têm apresentado algumas percepções que apontam para o estabelecimento de uma ligação entre o colonialismo, os direitos humanos e sofrimento. Este é o caso da obra de Upendra Baxi, que fez uma crítica às teorizações ocidentais do direito e promoveu um encontro fecundo entre a percepção dos Estudos Subalternos e a teoria dos direitos humanos.

Palavras-chave: Manifesto Antropófago, emoções, surrealismo jurídico, Estudos Subalternos, teoria descolonial, eurocentrismo, direitos humanos.

\footnotetext{
' Rechtskulturen Post-Doctoral Fellow, Humboldt University, Unter der Linden 6, 10099 Berlin, Germany.
} 
The critique of Eurocentrism can lead us to interrogate and stand back from rationalism itself-that peculiar species of European thinking and intellectual climate in which human rights theory was engendered-and to reflect on the role emotions and suffering can play in the construction of a theory of human rights. ${ }^{2}$ In contemporary thinking it is possible to point to a cluster of enquiries that have adopted the world system as their field of research, while working in the elaboration of a philosophy concerned with 'the other' and with the thematisation of concepts with emotional charge (Ward, 2004, p. 170). ${ }^{3}$ Thus, the reflection on politics and ethics developed in the context of the current process of globalisation has led Derrida to put the ideas of friendship and forgiveness at the centre of his cosmopolitanism (Derrida, 200I, 1997). ${ }^{4}$ Perhaps this trend in recent philosophy responds to what Gayatri Chakravorty has called the need for contemporary rights-based cultures to be supplemented by the "call of the other' (Chakravorty Spivak, 2003, p. 168). This orientation of critical thinking is part of the contemporary 'turn to emotions', which includes the insights offered by the critique of rationalism advanced in Latin America by Oswald de Andrade's Manifesto Antropófago (1928) and Luis Alberto Warat's Legal Surrealism, and by Subaltern Studies, in particular the work of Upendra Baxi. ${ }^{5}$

Latin American thinking-whose existence is still in doubt in some quarters as a remaining consequence of its colonial past and present-has been kept in the boundaries or outside the circuit of the wider contemporary debate. It even remains unknown throughout Latin America itself due to the high degree of isolation in which the cultural life of most of the countries of the region carries on still today. However, there are a number of trends and positions that are relevant to re-think human rights in a new light. Among them, the critiques of rationalism advanced by Oswald de Andrade and Luis Alberto Warat in Brazil and Argentina-where there is the possibility of integrating the emotions into human rights theory. ${ }^{6}$ Their criticism of rights starts out from a 'coming back' to the 'primitive mentality' and connects with the inspiration provided by Nietzsche and the European aesthetic vanguards of the $20^{\text {th }}$ century. Decolonial Theory, in particular the works of Enrique Dussel and Walter Mignolo, will also help us to delineate a thinking that locates itself in the Third World.

Sharing a preoccupation with those excluded from the 'world order' and the appeal to sensibility, Subaltern Studies have advanced some insights pointing at establishing a link between colonialism, human rights and suffering. Subaltern Studies constitute today an important area of investigation in both social sciences and the humanities. Their contributions to the field of history and cultural studies have been enormous and enjoy wide recognition. Less known are their explorations in the sphere of the theory of law. This is the case in the work of Upendra Baxi, who has offered a criticism of Western theorisations of law and crafted a fruitful encounter between the insights of Subaltern Studies and the theory of human rights. ${ }^{7}$

\section{The critique of rationalism from the perspective of the colonised}

As is the case with Nietzsche, Heidegger,Adorno and Horkheimer, some thinkers have pursued a critique of reason within the European horizon of understanding. The present critique emerges from a different point of view or, to be precise, from a different historical and geo-political location. It departs from the 'exteriority' of Europe or 'the exteriority of the excluded' (Dussel, 1998, p. 3 II) - from the position of the colonised peoples, or the Third World. From this standpoint, the critique of rationalism is not only an epistemological issue. At its roots also lies a political impulse, springing out from a consciousness that looks for autonomy and seeks a non-alienated understanding of the world. At this junction epistemological and geopolitical matters fuse, and an intellectual question becomes a political one.We are here in the field of what Walter Mignolo

\footnotetext{
${ }^{2}$ On the connection between human rights and emotions see Rorty (1994) and Barreto (20I la, 20I Ib).

${ }^{3}$ The work of lan Ward himself can be situated within this trend, particularly his Justice, Humanity and the New World Order (2003).

${ }^{4}$ If we are to believe Derrida, deconstruction is not entirely separated from emotions as some of his readers might think: 'Even if it appears very provocative to say it and even if I began by protesting, I think I was wrong. I am very sentimental and I believe in happiness; and I believe that this has an altogether determinant place in my work' (Derrida, 1996, p. 77). On Derrida and emotions see Terada (2001).

${ }^{5}$ The conditions of the encounter between a theorisation made from the perspective of a Latin American questioning and that of Subaltern Studies have been analysed elsewhere by Ranajit Guha. For Guha (200I, p. 36-37) the common ground of such a meeting lies in the 'global temporalities' they share-that of the times of postmodernity--and has been described as the 'convergence' of two perspectives with distinct characteristics. No less importantly, this relationship can also share the rationale of responding to the phenomena of colonialism and imperialism.

${ }^{6}$ Another possibility resides in the work of the Chilean philosopher Humberto Maturana (1988, p. 48-50), who speaks about the need for 'emotioning' to accompany and restrain the monopoly of rational thinking in modern culture.

${ }^{7}$ Commenting on the general orientation of perhaps his most famous text Baxi states: "I endeavour, in this work, to articulate a distinctive subaltern perspective on human rights futures" (Baxi, 2002a, p. xiii).
} 
calls the 'geopolitics of knowledge' (see Walsh et al., 2002). Thus, the epistemological critique of rationalism is accompanied by an account of the historical and cultural consequences of rationalisation. Modern reason is the object of critique because it is a key element in the process of domination of the non-European cultures. The hegemonic rationalist way of thinking was taken to the colonial world by conquistadors, colonisers, priests, lawyers, writers, grammarians and philosophers, and permeated the Non-European cultures through the process of modernisation and cultural domination of the life world that has gone on now for 500 years. Not only entire continents have been colonised but also languages, religions, cultures, memory and ways of thinking and of representing space, in the wake of the drive to refashion life according to the European template. ${ }^{8}$

Once a consciousness about the wiping out of entire indigenous cultures is reached, it is not difficult to understand the urge experienced by some Latin Americans to distance themselves from the hegemonic way of thinking, as breaking with the European domination can include the questioning of rationalism. A critique of reason in this direction has been attempted by a number of theories made in the Third World, which are part of the effort to break free from the tutelage and straitjacket of European thinking and culture. As the modern European model of thinking was, and continues to be, a tool in the process of domination and acculturation of the colonised world, Luis Alberto Warat points out in his 1988 'Manifesto of Legal Surrealism' that there is a need for challenging 'the monopoly of reason', for overthrowing the 'dominant rationalism' and for 'subverting Western rationality', a project that could lead to 'decolonising imagination' (Warat, 1988, p. 2-3, 9-10, 12).'

The imperative of confronting the modern intellectual climate and culture requires reformulating received concepts, but also questioning and transforming in a radical way the adopted or imposed structure of thinking. Our capacity for dreaming new ideas and worlds can be liberated from the configuration forced by colonial rationalisation-the colonisation of nonEuropean 'reasons'. The consequence of such an endeavour cannot be other than that of intellectual freedom, self-development and authenticity. The conversion of Western rationality or the disengagement from it operates as an exercise of 'resistance to alienation', or as a way of achieving emancipation-of recovering 'our au- tonomy' and of affirming 'our singularity' (Warat, 1988, p. 4-5, 10, 15). The historical challenges posed by our times, including those of confronting totalitarianism and of advancing democracy and human rights, make it necessary 'to get back to thinking what has been decreed unthinkable' (Warat, 1988, p. 4-I5). In this way Warat dares to consider the need to 'embrace an Adamic attitude [...] a primitive gaze', a 'primitive thought' or a 'primitive mentality' (Warat, 1988, p. 5, 9).

The same call to overcome the 'conquering thought' is found in Oswald de Andrade's idea of philosophical anthropophagi, which he expressed in 1928 as a theoretical strategy to deal with invasive European culture and which has been described as an 'indictment of Western metaphysics' (Castro-Kláren, 2000, p. 299). In his paradoxically Paris-born 'Anthropophagite Manifesto' Andrade embraces 'the primitive mentality' as his own and scolds those who, like the French anthropologist Lucien Lévy-Bruhl, consider non-European or nonmodern ways of thinking inferior: 'Against all importers of canned consciousness. The palpable existence of life. And the pre-logical mentality for Mr. Lévy-Bruhl to study' (Castro-Kláren, 2000, p. 299). Andrade even disputes the modern cultural history of the Americas when he provocatively insists: 'We never admitted the birth of logic among us' (Castro-Kláren, 2000, p. 299). Lévy-Bruhl had published in 1910 'Les fonctions mentales dans les societés inférieures' and in 1922 'La mentalité primitive', in which he studied the so-called pre-logical mentality of the 'primitives' and described it as a way of thinking distant from the principle of non-contradiction. Positing an opposition between 'primitive' and 'civilised' thought, Lévy-Bruhl could envisage only one possible outcome from this collision: the necessity for the 'primitive' to evolve towards the 'civilised' and to logical thinkingthe savage must be helped to progress and copy the 'higher' mental types observable among the 'advanced peoples'. ${ }^{10}$

The opposite applies to Andrade's critique of rationalism. His is not only a meta-epistemological questioning, but it also follows the impulse to rebuff the colonisation of primitive thinking. Andrade takes up 'irrationalism' by casting primitive thinking in a positive light. Latin America needs to ascertain the value and worth of its own way of thinking and to counteract the process of rationalisation of its culture. Andrade declared that his critique of modern reason did not have

\footnotetext{
${ }^{8}$ On the colonisation of language, memory and the representation of space see Mignolo (2003).

${ }^{9}$ I thank Pablo Gheti for having introduced me to the work of Warat.

${ }^{10}$ No wonder why, in a critical shift experienced at a late stage of his life, Lévy-Bruhl portrayed the 'Institut d'ethnologie' that he founded as 'a tool at the service of colonialism' (Gaillard, 2004, p. 89).
} 
guiding ideas: 'It has only stomach' (Prado Bellei, 1998, p. 91)." 'Four centuries of beef! How disgusting' was one of the slogans of the Anthropophagi movement, which grew out of Andrade's manifesto, and in whose rationale being European was a synonym of being a 'beef eater' (Prado Bellei, 1998, p. 93). It is in this sense that the refusal of rationalism becomes part of the emancipatory project of decolonisation of Third World cultures and thinking. Bellei explains:

Four centuries of European beef-eating refers to the period of civilised, overdressed oppression in which the colonisers used enlightened rationality to repress and destroy the irrational primitive cultures and peoples that practiced anthropophagi [...] For Andrade, what was being repressed was a form of primitive wisdom that the Brazilian modernista revolution should try to recover, redefine [...] in the preparation of the utopian future (Prado Bellei, 1998, p. 93).'2

Warat's characterisation of Western rationality substantially coincides with Andrade's account: 'Formal imagination' is 'the basic vocabulary of science and philosophy' (Warat, 1988, p. 5), and rationalism is a way of thinking orientated by logic and coherence as sine qua non elements that enable one to arrive at the truth. Warat depicts this imbalanced, one-sided emphasis as 'logomaniac' (Warat, 1988, p. 2). The rationalism that was developed in Europe has been unwilling to acknowledge its local and specific genesis. On the contrary, from its beginning it has been inclined to claim a universal validity, which in turn supposes a culture of exclusion. Descartes' inaugural version of rationalism knew no geographical or theoretical limits and became hegemonic in contemporary culture, despotically putting aside or silencing as illegitimate those ways of being and thinking in which 'reason', or European reason to be precise, was not in complete command. Thus, Western rationality is accompanied by a peculiar attitude of hostility towards difference, in particular towards emotions. Reason, 'logocentrism' or 'phalogocentrism' carry an 'absolute power' (Warat, 1988, p. 12) that tyrannically takes possession of every sphere of culture, driving out emotion and the heart, and condemning feelings to exile.

For Warat (1988, p. 12, 14), the 'world called Cartesian', or the corpus of modern rationality, can be described as a Manichean apparatus that 'ignores the passionate subject' and as a world 'where one loses also the right to passions'. It can also be seen as a hierarchical machine that cuts apart human beings into two opposing fractions, locates reason at the higher level or that of the 'truly human', while displacing passions, instincts and desire to the lower rank of the unworthy (Warat, 1988, p. 2-3). Ultimately, modern reason is a feature of the capitalist culture and it can be described as a 'market rationality that brings about the domination of the logic of sentiments' (Warat, 1988, p. 12-13). By contrast, the primitive mentality or 'late surrealism' - Warat's reading of surrealism - entails a 'revolution out of sentiment' that endeavours to apprehend the world 'much more by means of emotions than by means of thought' and that, while asserting that it is our passions which make us human, looks for some rebalancing that brings emotion and reason into a fruitful cooperative relation (Warat, 1988, p. 3, 10, 12).

Baxi (2002b, p. II3-II4) is also aware of the criminal record of reason in modern history and of how the rationalist climate has determined the substance and the form of the dominant theory of human rights. The narrative of suffering embedded in the 'subaltern rights-talk' opposes and supplements the rationalist mood of contemporary times and scholarship. One cannot but experience a strange discordance in listening to the voices of sorrow and tragedy as they bounce back at the dry and abstract hegemonic discourse on democracy and human rights theory, which remains 'sanitised' and purged of references to pain. If mentioned, suffering is just used as a rhetorical devise and generally does not play a crucial role in the construction of theories. Historically unable to adopt the standpoint of those who suffer, Western human rights theory 'disembodies human suffering' (Baxi, 2002a, p. 14) and neglects the fact that the physical consequences of the violation of rights are as important as its intellectual and legal connotations (Baxi, 2002a, p. 14).

The gulf between these two ways of speaking about human rights allows distinguishing between the discourse of the 'illustrado' and 'literate'-the intellectual of the West-and the narrative of the 'índio' and 'illiterate'- the victim of colonial violence. In the current conditions of globalisation the former articulates the discourse of the status quo, while the latter incarnates a subversive narrative. The human rights discourse characterised by conveying 'a sense of suffering' (Baxi, 2002a, p. xiii) not only challenges but also enriches the

\footnotetext{
"This is not strange to Nietzcshe's 'thinking with the guts'.

12 Paradoxically, the work of Andrade is situated within what was called in Brazil the Modernist movement, a name that responds to particularities of the local history of literature.
} 
dominant Western theories of human rights. A 'fuller advertence of the voices of human suffering' will put us on the path to make suffering central to the theory of rights, which can give origin to a novel paradigm, to a 'different kind of theorising', or to a 'new episteme' for thinking human rights. ${ }^{13}$ The critical impulse offered by Baxi will help us to think in a new light the human rights culture and the ethics of human rights.

\section{Human Rights culture, suffering and the ethics of solidarity}

The Subaltern Theory of human rights posits human rights in the global context and within the dynamics of the relationship between empires and colonies-in the middle of the violence of colonialism and the resistance to imperialism. What is immediately apparent from thinking human rights within the framework of the world system and from the standpoint of the Third World is that the victims of the violation of human rights are not only those that have been objects of abuse by nation states within their boundaries. One must also number among the damaged individuals, minorities and entire peoples trampled down under the advance of the empires driven by the search of power and wealth that have been engaged in plundering the colonised world for five centuries. It is at this point that the insight of the legal philosophy elaborated within the field of Subaltern Studies can be very enlightening. Developing one of the main tenets of Guha's work according to which Subaltern Studies speak from the perspective of the victims, the subaltern theory of human rights speaks from the point of view of the violated.

This move is the consequence of an explicit positioning of the theorist of rights in relation to the victims, in which she abandons the cool detachment favoured by rationalism, distance and time. Quoting Guha, Baxi (2002a, p. xiii) maintains that there is a need for those engaged in the elaboration of a theory of rights to incorporate a self-awareness about their own place and role in history, and about the choices they make when considering human rights issues. For those who for geographical or historical reasons do no find themselves already among the subaltern, to think from 'the standpoint of the suffering peoples' (Baxi, 2002a, p. x) encompasses a theoretical move that puts them in the position or 'the shoes' of the victims, and that considers the violation of the rights and its theorisation from the perspective of their experiences and interests. ${ }^{14}$ For those who think of themselves as belonging already to the peoples ravaged by colonialism, to think from this point of view is to recognise themselves as being one among the millions inhabiting the colonised continents and to consciously embrace their predicament and hopes. This does not imply any sort of identification with the view of the victims. While those who think from the Third World reclaim to validate their individual and particular view as such, the voice of the violated remains multiple and complex. Thinking human rights from the point of view of the violated neither supposes to speak on their behalf nor to represent them in the scholarly or public debate. ${ }^{15}$

Baxi's introduction of 'the language of the violated' transforms the quality of the human rights discourse (Baxi, 2002a, p. 4, 126). Speaking about human rights from the perspective of the victim means to create a discursivity on human rights that is expressed in terms of suffering. One is obliged to face nakedly the fact of suffering. For the victims, the violation of their rights does not mean first of all the breaching of constitutions or international treaties, nor the negation of political ideals or ethical principles. For the victims, violence has material consequences in the body and mind, and is cause of immediate distress and physical or psychological pain. ${ }^{16}$ The human rights theory can be constructed around human and social suffering because 'the authentically subaltern utterance has no other language

\footnotetext{
${ }^{13}$ In a tone not free of dualist connotations, Baxi says that the 'recovery of the sense and experience of human anguish provides the only hope there is for the future of human rights' (emphasis added) (Baxi, 2002a, p. v).

${ }^{14}$ This shift of attitude can also be accompanied by an intellectual repositioning of the Western subject that takes her from her own context to the context of the colonised as a consequence of realising that her supposedly universal ideas do not apply to all cases. The first and perhaps one of the most intriguing experiences of this sort may be that of Alvar Nuñez Cabeza de Vaca, a member of a Spanish $16^{\text {th }}$ century expedition to the coast of Florida, who lived for eight years among the natives and became a shaman (Cabeza de Vaca, 1964). 'Cabeza de Vaca', by the Mexican director Nicolás Echavarría, is a very engaging movie based on his diaries. A more contemporary attempt at a similar kind of transposition is that of Miguel Morey in Deseo de Ser Piel Roja. Novela Familiar (I 994). I thank José Bellido for bringing this book to my attention.

${ }^{15}$ Baxi formulates one of the classical questions of Subaltern Studies: 'On whose behalf may we speak when we speak of human rights?' Despite assuming a subaltern theory of human rights as a sort of voice person of the violated, Baxi recognises that no sophisticated self-comprehension of their role in history can ensure that those working under the perspective of the subaltern would be able to convey the complexity, sentiments and direction that arise from the historical fight of the peoples for human rights (Baxi, 2002a, p. xiii).

${ }^{16}$ Operating within the ethos of this language, the contemporary state of affairs of the Third World is characterised by Baxi as one in which a number of generations remains condemned to 'intense suffering'. In a similar way, the social costs of the ColdWar and the process of globalisation--the latest expressions of colonialism-are defined in terms of the suffering caused to the peoples of the Third World.
} 
that would enable the violated to express this violence' (Baxi, 2002a, p. 126). It is possible to speak about the victims of mass killings in the language of statistics or in the terms of a political discourse of denunciation of injustice. It is also possible to speak about the individual victims in terms of legal subjects whose rights have been infringed. However, the introduction of the language of the victims, an operation that encompasses a true 'blood transfusion', can supplement the discourse of the reconstruction of the history of a people, as well as the jargon in which reports on human rights abuses are written. The language of suffering is the immediate and sometimes the only speech or meaningful utterance available to those tormented by the torturers, to the mother facing the disappearance of her son, to the child who knows his father has been killed. Pain is also what generations have felt when they have been hammered by the diverse forms that the violence of imperialism has adopted over the centuries all over the geography of the South.

The language of suffering corresponds to the common sense of the victims, but it has not been admitted in the main body of the European theory of human rights. However, speaking about emotions and suffering in the context of a theorisation on human rights should not be considered odd. On the contrary, a theory that deals with the individual and social effects of events like those of torture, mass killings and slaughter of entire peoples, but in which suffering is not a key concept, must face doubts about its comprehensiveness and its ability to grasp the core of the topic about which it is speaking. Human rights abuses are phenomena inextricably bound up with pain, distress and desperation. So, it comes as a surprise to discover that there is no antecedent in the classic European theories of rights of a central reference to the suffering of the victims of the state. No wonder that the suffering of the colonial victims of imperialism do not have a place in the hegemonic theory of rights. ${ }^{17}$

Within the ethos of the language of the violated, Baxi's characterises the Third World as 'the suffering humanity' (Baxi, 2002a, p. I I3-I I4). In this notion the Third World is defined in terms of the pain it has endured over the centuries as a consequence of imperialism. Suffering becomes in this rights discourse one of the crucial aspects of the history of the Third World, a history of millions of individual lives turned to misery and destroyed, and a tale of genocide of entire peoples. This is the suffering of individuals, the unbearable pain of a child torn to pieces and devoured by dogs; the infinite pain of his mother, from whose breast he was pulled away. The concept of the 'suffering humanity' incarnates the few seconds or the long years in which the pain of the child and the mother was endured. We need to bring into consciousness this excruciating agony that has extended and multiplied across peoples and centuries. This is a suffering that permeates and taints the entire history of continents and our era. It is a pain that gets confounded with the spirit of the times. Speaking about how the twentieth century history of the European Jews can be summarised in the word 'Auschwitz', Lyotard (1997, p. 78) says that 'there is a sort of grief in the Zeitgeist'. The agony evoked by the words 'a suffering humanity' is of this quality. It is an affliction that evokes and convenes the torment of so many for so long.

At the same time, the concept of 'the suffering humanity' reclaims the right of the victims of imperialist violence to incarnate humanity and to be human. The invocation of Humanism in the Renaissance was made in order to identify certain sorts of humans and peoples and to exclude from these categories some other human beings, the barbari first of all (Fitzpatrick, 2003, p. 439). In order to justify the conquest of America and the Third World and to guarantee the stability of the colonial world order, a conceptualisation of the 'inhumanity' of the colonised was constructed and has been re-elaborated again and again until the present. Juan de Sepúlveda denied a human quality to the Indians in a philosophically and theologically exquisite argumentation, while the conquistadors referred to them as beasts. The marginalisation of the inhabitants of the Third World from the human species was accompanied by another strategy of segregation spelled out in the no less effective terms of race and their supposed inferiority in relation to those coming from across the Atlantic. But humanity is not a property owned exclusively by Europeans or by the West, nor are the inhabitants of the Third World 'less equal' than the folks of the North and the West, as it is still held today by the prejudices that feed racism and xenophobia in 'advanced' societies. Against this background that extends and pollutes the

\footnotetext{
${ }^{17}$ Recently a very interesting attempt has been made at establishing a relationship between suffering and the theory of human rights from a European perspective. It starts out from the awareness of the absence of such an approach in the whole body of the European tradition of natural and human rights, and invites cultivation of memory and a sensibility towards the suffering of the Europeans and of 'the others', adopting pain as the common experience of all human beings. Notwithstanding, despite its intention of avoiding the habitual flaw of a European thinking that claims to be universal while remaining unilateral and exclusive, this effort ends up falling into the same old skins as the suffering to which it refers is mainly that inflicted by nation-states in the history of Europe. Regrettably, memory of the suffering caused by the European empires does not have a place in this re-thinking of rights (see Gunther, 1999, p. II7-144).
} 
whole history of modernity, the expression 'the suffering humanity' reclaims humanity for the human species in its entirety, for the human as such. It does so in a peculiar and idiosyncratic way, bringing into awareness the role and the vicissitudes the excluded humanity has had to endure since the beginning of modernity.

The Third World is a humanity that suffers because it has been, and continues to be, the victim of pillage and genocide. Nonetheless, positing the Third World as a victim does not imply its identification with that condition, nor are the colonised identified with the wound inflicted by the conquerors. ${ }^{18}$ The memory of the violence of the past and the denunciation of the abuses of the present, accompanied by a will to point to those responsible and to those who have been or are subjected to plunder and destruction, does not necessarily mean colluding in a poignant and self-defeating process of victimisation of the Third World. Although an important part of its history, being a victim of genocide does not monopolize its past, the realities and the possibilities of the Third World.

In addition, to point to the existence of a sustained campaign of slaughter in modern history and to its victims does not necessarily lead to the conversion of those peoples into passive and submissive spectators of their own plight, or in masses waiting for redemption offered graciously by others. The subaltern is the victim, but those who have been converted into subalterns by the advance of imperialism are precisely the communities fighting for independence and against neo-colonialism.A judgement on past history by a moral and political consciousness and the endeavour for taking to a halt such a display of cruelty ask for a thorough investigation of the manifold crimes and for a clarification of who the perpetrators and the victims were ${ }^{19}$. For Dussel (1998, p. $3 \mathrm{II}$ ), to unveil or to discover the felonies of modernity, and to point to the victims outlines an 'ethical-critical consciousness' and constitutes a first step towards emancipation and the achievement of justice.

The telos of the theory and practice of human rights that emerges from the idea of a 'suffering humanity' resides in a commitment 'to give voice to human suffering, to make it visible', an enabling step towards global political consciousness and to an historical engagement with 'the alleviation of human misery and social suffering'-of the suffering of hundreds of millions of the 'wretched of the earth' (Baxi, 2002a, p. 3-4). A practice of human rights embedded in the ethos of the struggle for self-determination and independence is thus radically tied to the search to remove the conditions under which domination is exercised. There is a truly emancipatory sense at the core of the fight for human rights which, in the sphere of the neo-colonial world and globalisation, can be spelled out in terms of resistance to imperialism and the search for global justice. ${ }^{20}$

If, to imagine a theory and practice of human rights we follow Baxi throughout his denunciation of the consequences of imperialism and thus we listen to the 'tormented voices of the violated' (Baxi, 2002a, p. 4I), then the human rights culture becomes a response to the plight of the humanity that suffers. But such an admittance of suffering requires a specific quality that gives proper and adequate answer and credence to the phenomenon with which it is dealing. Although a rational reaction and comprehension is not only feasible but also represents the standard rejoinder to human rights violations, a reply involving feelings or made in terms of the pain they involve is possible too and perhaps more adequate. In this way the phenomenon of 'human sensibility' (Baxi, 2002a, p. 4l) is brought to the realm of human rights as a capacity for apprehending the world and as a force for human rights and moral progress. Sensibility alludes here to a feature of human beings that is as human as reason.Aristotle distinguished the human from the beasts by the faculty of reasoning, and modern subjectivism since Descartes has led to the enthronement of the identification of reason with human nature. However, regardless of the endurance of the Aristotelian idea, nor the hegemony of a rational understanding of humanity in contemporary culture, we all can also agree with the common sense affirmation according to which the humanity of human beings can be recognised by their capacity for sentiments. ${ }^{21}$

In speaking about sensibility as a competence for feeling emotions, Baxi (2002a, p. 4I) is not only referring to an ability residing in individuals but also to a 'moral collective sentiment'. In the framework of a meditation on human rights located in the horizon of the worldsystem, the collective nature of the capacity for feelings extends well beyond the borders of community and society. In a time of globalisation such a faculty has worldwide characteristics. In this way, Baxi postulates

\footnotetext{
${ }^{18}$ Sarah Ahmet (2004) has taken distance from the Subaltern perspective on the basis of a supposed identification of the victim with the wound.

${ }^{19}$ Within this rationale it is possible to say that a theory of human rights which refuses to speak about the victims or that precludes the possibilities of those damaged by violence to call themselves victims blinds itself to history, and conspires for the perpetuation of the culture of not allowing the voices of the violated to be heard.

${ }^{20}$ In a similar sense, Baxi considers that the sense of postcolonial constitutionalism and law is that of being a site of resistance to 'global economic constitutionalism' (Baxi, 2005, p. 552).

${ }^{21}$ It is the inability to build robots with feelings that largely allows distinguishing today between cyborgs and human beings.
} 
the existence of a 'global affectivity' with moral consequences, or a 'global moral sentiment', which would be part of our contemporary global culture (Baxi, 2002a, p. I 16). Such an idea points to a hidden or not yet properly recognised and thematised feature of contemporary culture, a realm of emotions that pervades and traverses culture as a whole, and that remains present not only in the ambit of individual cities and nations. It relates to the phenomenon of the world culture, whose configuration was born with the arrival of Columbus in America and the circumnavigation of the world, and whose contours and traits are beginning to emerge more clearly. The sorrow that marks the spirit of our times requires a new culture. The existence of a 'suffering humanity' and the defence of its rights demand the strengthening of the capacity of the contemporary global and postmodern culture to take notice of that humanity and to be sensitive to that suffering. A human rights culture embedded in this global phenomenon of moral sensibility could contribute to enlarge the appeal of rights as political ideals and legal norms, and supplement the fight for human dignity that is waged following the rules of rational political debate and criticism.

Re-thinking human rights from the point of view of the subaltern does not only lead to the introduction of the language of the suffering of the victims of the Third World in the discourse of human rights, to the description of human rights culture as a web of emotions and to the adoption of global sensibility as a reservoir and a source for the struggle for human rights. The presence of a layer or a sphere of emotions in contemporary culture has not only cultural connotations but also moral ramifications. Thus, this re-interpretation of human rights also has to do with a re-thinking of the ethics of rights. The morality elaborated under the modern premises of reason needs to be complemented by a dialogue with an ethics that finds its content in this pool of emotions that is part of the global culture. For Baxi (2002a, p. 4I), this new ethics is an 'emerging global ethics [...] of movements of human solidarity'.

\section{A cannibalistic theory of Human Rights}

For centuries the Europeans have denigrated the peoples of the Third World as barbarians. In the justification of such an accusation the trope of the cannibal played a crucial role, becoming one of the main justifi- cations for the mass murder that the war of conquest came to be: the cannibalistic peoples were precisely those in need of being civilised and their depravity and horrible sin justified all the means to achieve such an end, including their extermination (Hulme, 1998, p. 1415).

But if we look at anthropophagi from the point of view of the peoples that practiced cannibalism as a custom, we could get a different picture. For the Wari, an Amazonian tribe that entered into contact with the modern world in the 1950s, burying was degrading and disrespectful to the dead, while horrifying and emotionally troubling and sad for the relatives. Are we modern readers able to find in the Wari a sentiment of a similar character but of opposite rationale to that which made Antigone to fight for the burying of her brother? At the time of the Conquest some of the native tribes used to eat those of their associates who died-out of a sort of sympathy for the deceased-whom they did not want to leave rambling around alone or rotting in the wet and dirty soil, as well as in order to lessen their sadness. They also used to eat their enemies in order to get the strength of their spirit (Conklin, 200I, p. xvii-xix, 32). It is likely that, in continuing with this well-established tradition, when the Spanish arrived in America some conquistadors and bishops have been eaten by the natives.

In his 1928 'Anthropophagite Manifesto', Oswald de Andrade embraced and transformed this claim into a positive principle and framed cannibalism as a method or cultural strategy for dealing with the European heritage. The deglutition and devouring ${ }^{22}$ of European thinking combines an aggressive and a constructive attitude. It is, first of all, a rebellion against the imposition and the impersonation of imperial intellectual models and ways of thinking, and the reproduction of their ideas. The mastication, swallowing and digestion of European culture allude to the critique to which European thinking is submitted: 'The cannibal devours the coloniser selectively and critically, producing a dialogical upsetting, a carnivalised movement of native and foreign cast' (Perrone, 1996, p. 52). On the productive side there is the digestion or absorption of the European heritage, that feeds new intellectual processes and that results in its re-elaboration in the terms of a Third World perspective and gives impulse to an autonomous thinking. The complexity of such a process results in a non-naïve and

\footnotetext{
${ }^{22}$ Cannibalism is not completely strange to the European civilisation and philosophy anyway. This is not only because Europe has an ancient tradition of anthropophagi. Suspicions have already been expressed by Peter Fitzpatrick about the existence of commonalities between philosophical cannibalism and deconstruction, particularly regarding some aspects of the reflection developed by Derrida in his 'Politics of Friendship' (1997). In this sense we can speak of the 'deconstructive' qualities of anthropophagic thinking, or about the 'cannibal to come' that resides in deconstruction.
} 
non-dualist process of cultural and philosophical syncretism. In a similar sense, working on the ideas developed by Andrade, the Brazilian poet Haroldo de Campos spoke of a 'transcultural anthropophagi' as an emancipatory project that thinks 'the national in its dialogical relationship with the universal'. De Campos included in this program of 'transculturation' the works of Latin American writers like Jorge Luis Borges and Octavio Paz (see Prado Bellei, 1998, p. 101). Thus, the consumption or eating of the heritage of the dominant nations or empires becomes an anti-colonial act of intellectual emancipation.

\section{Questions in place of a conclusion}

The pain evoked by Baxi's notion of a 'suffering humanity', which marks the spirit of our times, challenges the philosophical understanding of the Occident and necessitates a thought lively enough to ensure its apprehension. Can we hear the voice of the victims of colonialism? Is the contemporary consciousness sensitive enough to register or to 'grasp' such a grief? Is reason alone competent to give account of the spirit of the times we live in? Can the cold reason be 'warmed up' and softened? Is it redeemable? How to imagine a world guided not only by reason but also by the heart? How to think the existence of a culture of sentiments in the global geography in the midst of raging neo-colonialism and cold-blooded capitalism? In the context of the modern cultural and sociological conditions, how is it possible to cultivate and strengthen a culture of emotions? How we are going to imagine an ethics and a culture of human rights that respond to suffering humanity? How can an ethics of solidarity contribute to reinforce the contemporary, postmodern or decolonial global moral sentiment and to make the human rights culture more powerful? And what does 'human solidarity' mean in this context? This series of conjectures and questions guide this reflection, but they remain open to be answered in new explorations.

\section{References}

AHMET, S. 2004. The Cultural Politics of Emotions. Edinburgh, EUP, 224 P. ANDRADE, O. de. 1928. Manifesto Antropófago. Available at: http:// www.ccgsm.gob.ar/areas/educacion/cepa/manifiesto_antropofago.pdf. Accessed on: 02/03/2014.

BARRETO, J.M. 201 l a. Ethics of Emotions as Ethics of Human Rights: A Jurisprudence of Sympathy in Adorno, Horkheimer and Rorty In: C. DOUZINAS; C. PERRIN (eds.), Critical Legal Theory. London, Routledge, p. 84-II0.

BARRETO, J.M. 20I l b. Rorty and Human Rights: Contingency, Emotions and How to Defend Human Rights Telling Stories. Utrecht Law Re- view, 7(2):93-I | 2. Available at: http://www.utrechtlawreview.org/index. php/ulr/article/viewFile/I64/I63. Accessed on: 02/03/20I4.

BAXI, U. 2002a. The Future of Human Rights. New Delhi/Oxford, Oxford University Press, $184 \mathrm{p}$.

BAXI, U. 2002b. Global Justice and the Failure of Deliberative Democracy. In: O. ENWEZOR et al. (eds.), Democracy Unrealized: Documenta I I-Platform I. Ostfildern Ruit, Hatje Cantz Publishers, p. I3 I-I 54.

BAXI, U. 2005. Postcolonial Legality. In: H. SCHWARZ; S. RAY (eds.), A Companion To Postcolonial Studies. Oxford, Blackwell, p. 540-555.

CABEZA DEVACA,A. 1964. The Journey of Alvar Núñez Cabeza de Vaca. Chicago, Rio Grande Press, $231 \mathrm{p}$.

CASTRO-KLARÉN, S. 2000. A Genealogy for the 'Manifesto antropófago', or the Struggle between Socrates and the Caraibe. Neplanta: Views from South, I (2):295-322.

CHAKRAVORTY SPIVAK, G. 2003. Righting Wrongs. In: N. OWEN (ed.), Human Rights, Human Wrongs: The Oxford -Amnesty Lectures 2001. Oxford, Oxford University Press, p. 164-227.

CONKLIN, B. 200I. Consuming Grief. Compassionate Cannibalism in an Amazonian Society. Austin, University of Texas, 285 p.

DERRIDA, J. 200I. On Cosmopolitanism and Forgiveness. London, Routledge, $60 \mathrm{p}$.

DERRIDA, J. 1997. Politics of Friendship. Verso, London, 308 p.

DERRIDA, J. 1996. Remarks on Deconstruction and Pragmatism. In: C. MOUFFE (ed.), Deconstruction and Pragmatism. London/New York, Routledge, p. 79-98.

DUSSEL, E. 1998. Ética de la Liberación en la edad de la globalización y de la exclusión. Madrid,Trotta, $661 \mathrm{p}$.

FITZPATRICK, P. 2003. 'Gods Would Be Needed...':American Empire and the Rule of (International) Law. Leiden Journal of International Law, I6(3):429-466.

GAILLARD, G. 2004. The Routledge Dictionary of Anthropologists. London, Routledge, 394 p.

GUHA, R. 200I. Subaltern Studies: Projects for Our Time and their Convergence. In: I. RODRÍGUEZ (ed.), The Latin American Subaltern Studies Reader. Durham, Duke University Press, p. 35-46.

GUNTHER, K. 1999. The Legacies of Injustice and Fear: A European Approach to Human Rights and Their Effects on Political Culture. In: P. ALSTON; M.R. BUSTELO; J. HEENAN (eds.), The EU and Human Rights. Oxford, Oxford University Press, p. II 7-I46.

HULME, P. 1998. The Cannibal Scene. In: F. BARKER; P. HULME; M. IVERSEN (eds.), Cannibalism and the Colonial World. Cambridge, Cambridge University Press, p. I-38.

LEVY-BRUHL, L. 1910. Les fonctions mentales dans les societés inférieures. Paris, Les Presses Universitaires de France, 46I p.

LEVY-BRUHL, L. 1922. La mentalité primitive. Paris, Les Presses Universitaires de France, $537 \mathrm{p}$.

LYOTARD, J.-F. 1997. The Postmodern Explained: Correspondence, 19821985. Minneapolis, The University of Minnesota Press, I4I p.

MATURANA, H. 1988. Reality:The Search for Objectivity or the Quest for a Compelling Argument. The Irish Journal of Psychology, 9(I):25-82. MIGNOLO,W. 2003. The Darker Side of the Renaissance: Literacy, Territoriality and Colonisation. Ann Arbor, University of Michigan Press, 463 p. MOREY, M. 1994. Deseo de ser piel roja: novela familiar. Barcelona, Anagrama, $219 \mathrm{P}$

PERRONE, C. 1996. Seven Faces: Brazilian Poetry since Modernism. Durham, Duke University Press, 234 p.

PRADO BELLEI, S.L. 1998. Brazilian Anthropology Revisited. In: F. BARKER; P. HULME; M. IVERSEN (eds.), Cannibalism and the ColonialWorld. Cambridge, Cambridge University Press, p. 87-109.

RORTY, R. 1994. Human Rights, Rationality and Sentimentality. In: S. SHUTE; S.L. HURLEY (eds.), On Human Rights:The Oxford Amnesty Lectures 1993. New York, Basic Books, p. II-I34.

TERADA, R. 200I. Feeling in Theory: Emotion after the 'Death of the Subject'. Cambridge and London, Harvard University Press. 
WALSH, C.; SCHIWY, F.; CASTRO-GÓMEZ, S. (eds.). 2002. Indisciplinar las Ciencias Sociales: geopolíticas del conocimiento y colonialidad del poder: perspectivas desde lo Andino. Quito, USAB/Abya Yala, 247 p.

WARAT, L. 1988. Manifesto do surrealismo jurídico. São Paulo, Acadêmica, $103 \mathrm{p}$.

WARD, I. 2003. Justice, Humanity and the New World Order. Burlington, Aldershot, $184 \mathrm{p}$.
WARD, I. 2004. Introduction to Critical Legal Theory. London, Cavendish, $215 \mathrm{p}$.

Submetido: $10 / 1 / / 2013$

Aceito: $21 / 11 / 2013$ 